\title{
Exploring interventions in urban form which can enable better population health
}

\author{
Brydie Clarke $^{\mathrm{a}}$, Terry Jenvey ${ }^{\mathrm{b}}$, Nicole Vickridge ${ }^{\mathrm{c}}$ \\ ${ }^{a}$ Research and Evaluation Officer, Knox City Council, Brydie.Clarke@knox.vic.gov.au \\ ${ }^{\mathrm{b}}$ Coordinator Healthy Workplaces, Knox City Council \\ ${ }^{\mathrm{c}}$ Coordinator Strategic Planning, Knox City Council
}

\begin{abstract}
Knox City Council is one of 12 sites in Victoria where the 'Healthy Together Communities' Initiative is being delivered. Focusing primarily on reducing rates of obesity, physical inactivity, smoking and alcohol misuse, this initiative aims to use a systems approach to support healthy behaviours. This has prompted further investigation by Knox City Council into how its built environment may be influencing the health of its residents. The purpose of this study was to examine the urban form of two suburbs within the municipality, Wantirna-Wantirna South and Rowville, to identify how it can influence the rates of physical activity and therefore also potentially the rates of overweight and obesity. This comparative case study investigation used an exploratory, observational approach to understand how differences in urban form (i.e. land use mix, transportation networks, access to green space) may influence PA. It found that Wantirna-Wantirna South did not differ remarkably from Rowville in terms of social and other demographic characteristics. However, there were numerous small but cumulative differences across suburbs which may be influencing the rate of incidental physical activity. These included size of dwellings, land-use zoning, density of playgrounds, and modes of transport (i.e. active or motorised). Differences in the built form existed between the two suburbs which may, in part, explain the increased risk of obesity in Rowville. Future strategic and urban planning decisions for the suburb of Rowville and City of Knox should consider the potential impact upon the health of the population.
\end{abstract}

\section{Introduction}

In 2011 Knox City Council was one of 12 sites in Victoria to receive 'national partnership agreement' funding under Healthy Together Communities, a communitybased preventative health initiative. At Knox City Council this has lead to the Healthy Together Knox initiative. 
Healthy Together Knox aims to improve people's health where they live, learn, work and play. It focuses on addressing the underlying causes of poor health in workplaces, children's settings, and communities by encouraging healthy eating and physical activity, as well as reducing smoking and harmful alcohol use. The intervention uses a systems approach to implement a range of activities including development of health promoting policies and plans, delivery of local prevention services and programs, and through social marketing strategies (Department of Health 2013).

This paper explores differences in the physical activity environment in the Knox city suburbs of Wantirna-Wantirna South (where the population has a relatively low risk of obesity) and Rowville (where the risk of obesity is high) in eastern Melbourne. The purpose of this research is to understand the differences in the built environment between these two suburbs (such as open space, density of playgrounds and access to public transport), and how these differences might be contributing to the variation in the risk of obesity observed between the two suburbs. In the short term, the findings from this paper will contribute to the development of a local area plan for Rowville.

This paper begins by providing a summary of the Healthy Together Initiative and the complex nature of the issues and ambitions of the partnership. It then offers a brief review of the existing literature relevant to land use planning and design, and its effects on physical activity and obesity. The paper then undertakes a comparative case study investigation utilising an exploratory, observational approach in attempting to understand how different elements of the physical activity environment may be influencing the relatively high risk of obesity facing Rowville residents compared to Wantirna-Wantirna South. The findings from the case studies are then considered within the context of the existing literature.

\section{Background and literature review}

\section{Knox Preventative Health Partnership}

The Victorian 'Healthy Together' initiative is a community-based health promotion program. Knox is one of 14 Councils in Victoria to partner with the State Government to implement this local health promotion model over four years. Both the Knox and Victorian State initiatives' primary aims include reducing unhealthy weight in children and adults, increasing fruit and vegetable intake, increasing physical activity, and reducing smoking rates and alcohol use. Knox City Council was selected largely due to the highly varied geographical distribution of health outcomes, particularly in relation to 


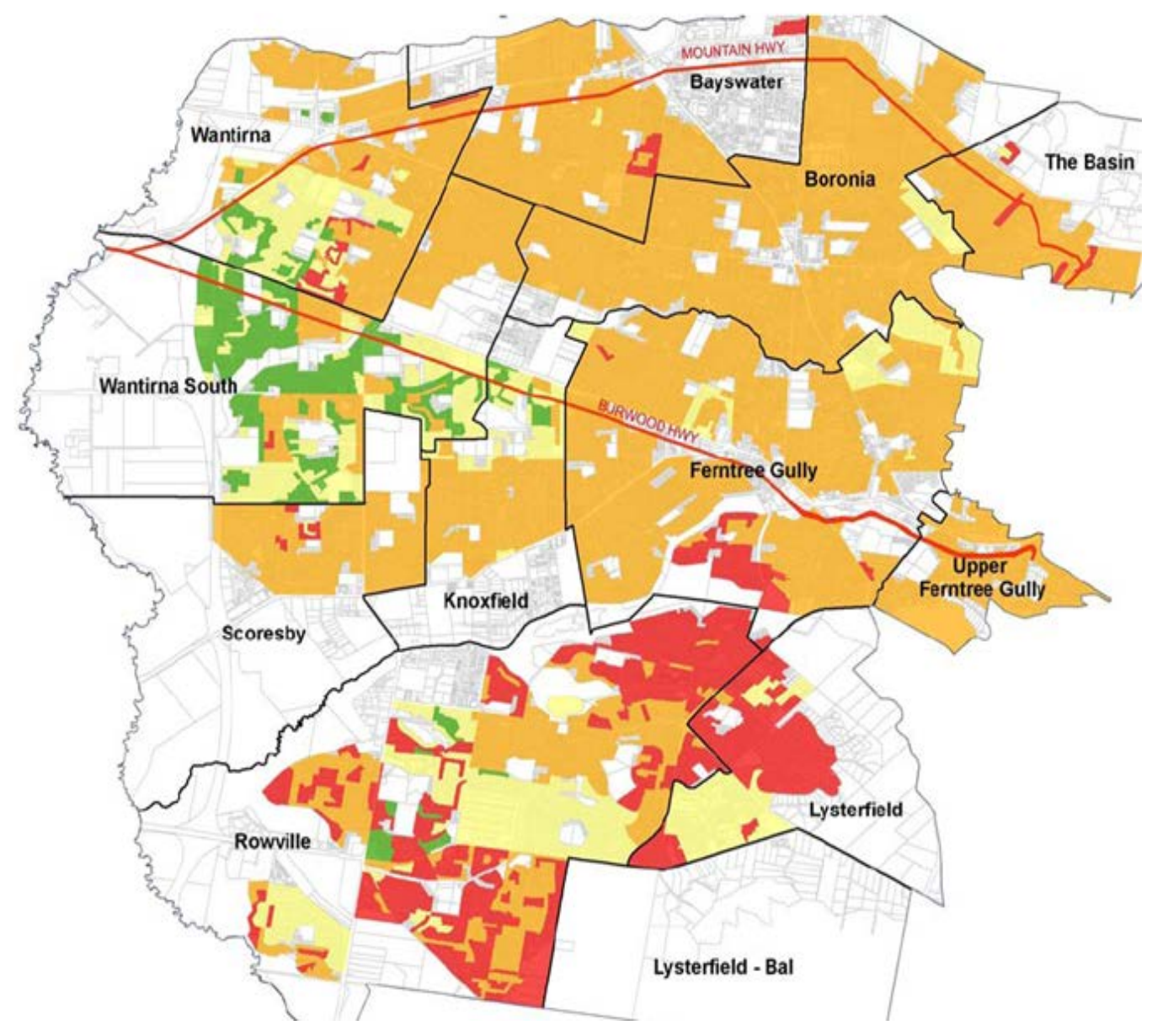

\begin{tabular}{ll}
\hline Percentage of overweight/ obese & Description \\
\hline Less than $40 \%$ & Less than state average (what we are aiming for) \\
\hline $40 \%$ to $49 \%$ & About average (State average 49.1\%) \\
\hline 50 to $53 \%$ & Above average \\
\hline More than $53 \%$ & Higher above average \\
\hline
\end{tabular}

Fig. 1. Relative risk distribution map for overweight and obesity in the Knox municipality.

Source: Modelled from Victorian Population Health Survey 2008 and Department of Health, Mosaic ${ }^{\odot}$ unpublished data. Information in Figure 1 is based on the modelled relative risk distribution (rather than actually sampling large numbers of residents directly). 
overweight and obesity (see figure 1). In addition, there is a significant need to improve the dietary and weight outcomes of Knox as highlighted by the below statistics:

- Forty-nine percent of Knox adults are at an unhealthy weight (where BMI is greater than 25)

- There is a low fruit and vegetable intake in Knox (49 per cent of employed people and 43 per cent of young people don't consume enough fruit and vegetables)

- There are generally low levels of physical activity, with only 65 per cent of residents reaching sufficient levels (only 15 per cent of young people exercise every day).

This particular study sought to focus on one of these issues, investigating the physical activity environment and its association with overweight and obesity - although it must be acknowledged that obesity is caused by complex interaction of factors, with insufficient physical activity, overconsumption of energy, and genetics all playing roles (Waters et al. 2011; Wyatt et al. 2006).

As with the rest of the Australian population, obesity is a significant cause of morbidity for the residents of Knox (ABS 2006). Australia is one of the world's most obese nations with over half of adults and a quarter of children and adolescents being classed as overweight or obese (NPHT 2009). The condition has now overtaken smoking as the leading cause of premature death and illness in Australia (The Age 2010).

Figure 1 (above) shows the relative risk for obesity in Knox. What is striking about this map is the large concentration of green (relatively low risk) in the north west of the municipality around the suburbs of Wantirna and Wantirna South, and large areas of red (relatively high risk) in the southern parts of the municipality largely centred around Rowville. This disparity is the focus of the comparative case study investigation.

Across the Knox local government area (both Wantirna-Wantirna South and Rowville), residents' participation in structured physical activity is comparable to state averages, however levels of incidental physical activity is lower, perhaps indicating that environments are not conducive to this form of activity (Data modelled from Victorian Population Health Survey 2008 and Mosaic@, Department of Health).

\section{Literature review}

Knox City Council recognises the role that both social and environmental determinants play in the development of obesity. This is demonstrated in figure 2, which highlights how extremely complex and multifactorial the aetiology of obesity is. Although there are a multitude of factors that influence body weight, there is a growing 
body of evidence supporting the link between physical inactivity and increased BMI, leading to overweight and obesity (Waters et al. 2011; Wyatt et al. 2006; Sparling et al. 2000). Modern environments have tended to lead to less exercise, due mostly to reduced occupational activity, more car use, less walking, and more passive modes of entertainment (Moodie et al. 2006).

Importantly, what figure 2 does is group the major influences of obesity, highlighting that the 'physical activity environment' includes aspects of the built form, such as:

- perceived danger in the environment (safety and perceptions of safety)

- access to opportunities for physical exercise (outdoor and indoor), including opportunities for team based activity (formal and informal)

- dominance of motorised transport and opportunities for un-motorised transport (how people move and opportunities for incidental activity)

- walkability of living environment (quality or amenity of the environment).

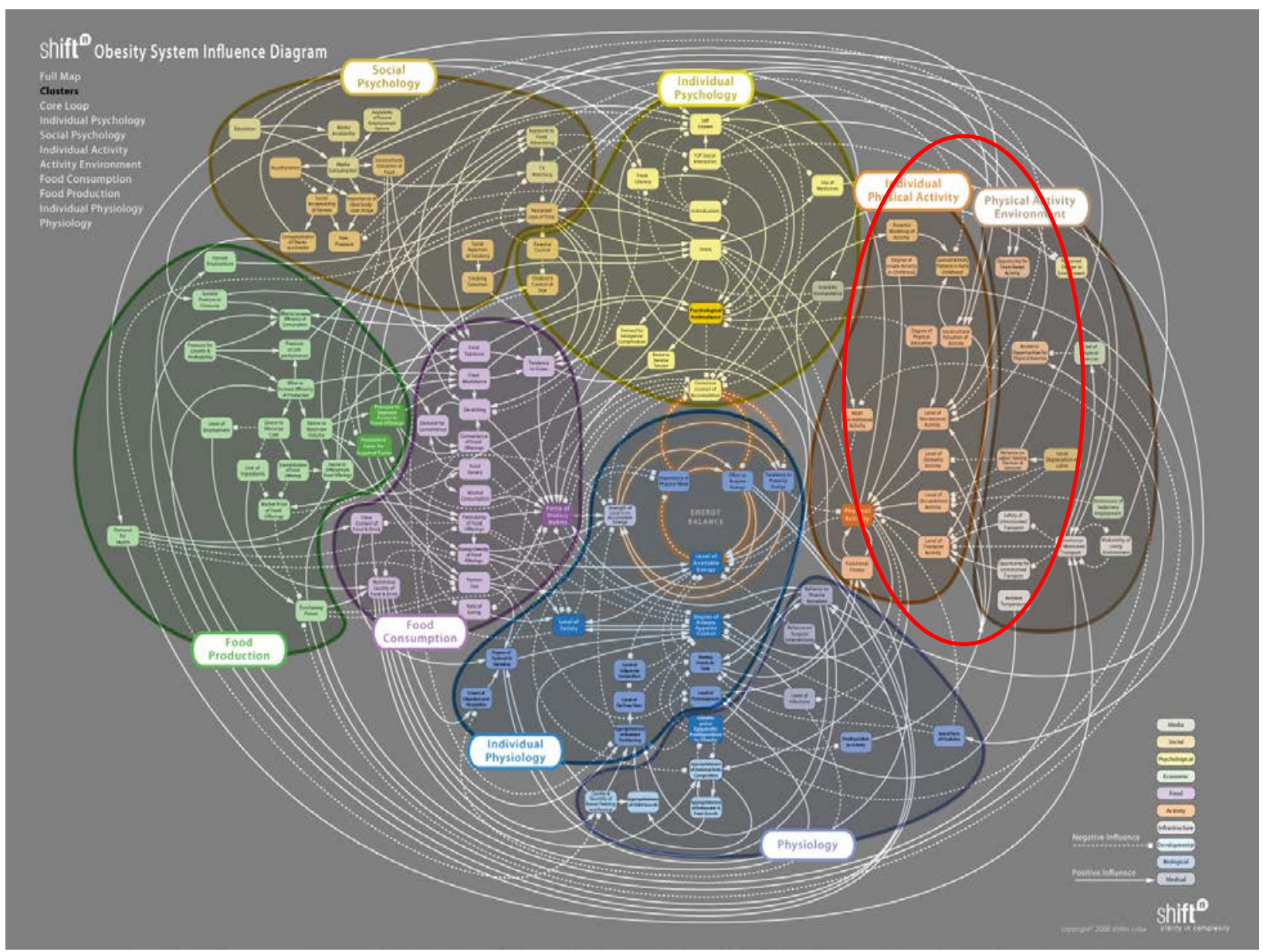

Fig. 2. Obesity system influence diagram.

Source: Vandenbroeck, Goossens \& Clemens 2007. 
The built environment refers to aspects of our surroundings that are created or modified by people rather than occurring naturally (VicHealth 2010). It includes homes, neighbourhoods, schools, workplaces, parks, recreation areas and transport systems (including public transport, footpaths and roads). The built environment can either facilitate or discourage physical activity. According to VicHealth (2010, p. 5) consideration should be given to aspects of the built environment that have a significant impact on levels of physical activity, including: the neighbourhood and road environment; the amenity of the neighbourhood; and proximity to a variety of destinations.

It is acknowledged that 'environments that people build and inhabit provide potential opportunities and barriers to engaging in physically active lifestyles' (Duncan et al. 2005, p. 1). Increasing evidence from both the planning and public health disciplines highlight how planning for urban form can enhance incidental physical activity. Numerous studies now support the role of built form and design, urban material use, transportation linkages, and maintenance of recreational and green space in enhancing physical activity (Frank et al. 2006; Frumkin et al. 2004; Jabereen 2006). There is now supportive evidence to suggest that pedestrian travel increases when route directness and pedestrian facilities are improved (Cao, Handy \& Mokhtarian 2006). Ensuring that pathways are linked, have safe street crossings with adequate lighting, and are of good placement and construction can substantially increase the number of individuals walking and reduce vehicle use in a community (Capon \& Blakely 2007; Greenwald \& Boarnet 2001). Proximity is also important, as adults are more likely to walk if they have a variety of destinations within 400 metres. Research has also found that the closer sports centres and parks are to young people, the more likely they are to use them (Sunarja, Wood \& GilesCorti 2008; Garrard 2009; Kelty, Giles-Corti \& Zubrick 2008). Furthermore, reviews of the transportation research and urban planning literature indicate that ease of pedestrian access to nearby destinations is related to active transportation choices, particularly walking (Owen et al. 2007, p. 379).

The physical attributes of residential neighbourhoods, particularly the connectedness of streets and the proximity of destinations, can influence walking behaviours (Owen et al. 2007, p. 378). Numerous studies show that people who live in more walkable communities (i.e. communities offering relatively greater proximity to numerous destinations, as well as high levels of connectivity between those destinations) are more physically active and less overweight than people in less walkable communities (Norman et al. 2006, p. 118).

Street design has also been recognised as a factor in improving walking and cycling levels within urban areas (Frank et al. 2006). For example, residents of Perth who had 
trees or no major traffic on their street were 50 per cent more likely to achieve healthy levels of walking than those living on streets with no trees or major traffic (Giles-Corti \& Donovan 2003). Similarly, those with access to 'attractive' parks (measured by tree shade, walking paths, water and bird life) were 50 per cent more likely to achieve high levels of walking than those with access to 'unattractive’ parks (Giles-Corti et al. 2005). A recent review of the health benefits of green space reported an association between perceived safety and physical activity levels (Lee \& Maheswaran 2010, p. 218). For example, the state of disrepair of green space negatively affects its use by making it feel less safe. Most of the studies in this review supported the positive effect that green space has on health, though ultimately the complexity of the relationship meant that establishing causation between green space and health was difficult to achieve (Lee \& Maheswaran 2010).

The role of public green spaces in facilitating higher levels of human health is becoming more well-known (Lee \& Maheswaren 2010), and some studies argue that incorporating planning principles that recognise and prioritise the natural environment is crucial to ensuring positive health outcomes for residents (Maller et al. 2008). In particular, environmental factors such as the quality and accessibility of green space affects its use for physical activity. Residents choose to use green spaces not only for their features, but also the condition of those facilities and attributes (Lee \& Maheswaran 2010). Therefore it is important to look beyond the total supply of green space.

Urban environments - in terms of the location of community spaces, shops and service destinations - can also encourage physical activity to promote health outcomes (Capon \& Blakely 2007). Planning that situates such facilities along mass transit routes has been demonstrated to improve physical activity levels (Frank et al. 2006) as well as ensure economic viability for businesses (Capon \& Blakely 2007). Systematic reviews have concluded that built-environment attributes (especially land-use patterns) are consistently related to physical activity in general, and to active transportation in particular (Owen et al. 2007, p. 378).

Housing density and mix also has the capacity to impact on travel and walking behaviour and can therefore influence health (Owen et al. 2007; Frank et al. 2006). Density, used in combination with land use mix, is increasingly acknowledged as an important way to promote incidental physical activity and to support public transportation usage (Kent et al. 2011). Furthermore, there is growing evidence for mixed density residential designs supporting reductions in vehicle use, enhancing a greater sense of community, and supporting overall health equity (Jabareen 2006; Wilkinson \& Pickett 2009). 
Given the growing evidence outlined above, several key organisations have advocated for changes to the built environment to encourage physical activity. The National Heart Foundation (National Heart Foundation [Victoria Division] 2004) states that planning for healthy places to live, work and visit can be encouraged by providing the following:

- Well planned networks of walking and cycling routes

- Streets with direct, safe and convenient access

- Local destinations within walking destinations from homes

- Accessible open spaces for recreation and leisure

- Conveniently located public transport stops

- Local neighbourhoods fostering community spirit.

The Heart Foundation highlights the role of urban planning in supporting health, stating:

When 'health' is integrated into planning the choice for people to be active becomes more convenient, easy, safe and enjoyable. Providing convenient, easy-to-access built environments that encourage people to be 'out and about' on a daily basis will contribute to a more active and vibrant society (Heart Foundation of Australia [Victorian Division] 2004, p. 7).

While many planners recognise that urban planning influences health, they do not normally perceive that it is their role to focus on or study the relationship. At the same time, public health professionals are beginning to take a real interest in spatial planning. Advocacy and specific population programmes are not enough to change behaviour (i.e. to persuade people to exercise more) when the form of towns and cities are working against them (Barton 2010, p. 96). One of the more challenging aspects of this work for planners and public health specialists is the need to cross professional boundaries and norms (Higgins 2010, p. 108).

\section{Research aims}

The aim of this research was to establish the differences in physical activity environments between two suburbs in the Knox City municipality (Wantirna-Wantirna South and Rowville), and to consider how these may be contributing to the observed variance in the risk of obesity between the two areas. The review of the literature summarised above also informed which characteristics of the built environment would be analysed in this study. These potential modulating factors for physical activity include:

- $\quad$ safety and perceptions of safety 
- opportunities for un-motorised transport

- distance to public transport

- access to open space, playgrounds and shared space

- $\quad$ access to leisure facilities

- land use mix.

This paper provides an important input to the development of a local area plan for Rowville. While the Plan was initially conceived as a review of the land use and development controls within the current structure the Rowville Plan represents an opportunity to develop a much more holistic strategy for the next 20 years for the largest suburb in Knox. The current focus of the Rowville Plan is around understanding the drivers of change; a means of understanding not only the current needs, but also the future needs of this community.

\section{Methods}

This study sought to explore the demographic differences between Rowville and Wantirna-Wantirna South and to assess the impact of the built environment upon physical activity. The findings will be used to identify possible interventions in the built environment to reduce the relative risk of obesity and enable better population health in Rowville through the development of the Rowville Plan.

A comparative case study was possible between the 3152 (Wantirna and Wantirna South) and 3178 (Rowville) postcode due to the similar size and population of these two areas.

Tab. 1. Area and population comparison between WantirnaWantirna South and Rowville.

\begin{tabular}{lll}
\hline Area & Size (ha) & Population \\
\hline Wantirna and Wantirna South & 2,238 & 31,237 \\
\hline Rowville & 2,169 & 34,77 \\
\hline
\end{tabular}

A case study approach has been used as it allowed a comprehensive exploration of each defined case using various data accumulation methods.

Following on from the literature review, this study firstly explored demographic characteristics for each suburb before assessing the social determinants that may underlay the observed variance in the risk of obesity between the two areas. The study then sought to explore differences in a number of physical environmental factors which 
the literature suggests may influence physical activity, before assessing their role in affecting obesity levels within each of the suburbs.

\section{Case Studies}

\section{Case one: Rowville}

At the 2011 Census, Rowville had a population of 34,777. Rowville is named after the Row family, whose property Stamford Park was established in 1882. Rowville is one of the largest suburbs in the south-east of Melbourne. Rowville Post Office opened in December 1905. Rowville has developed rapidly over the 1980s and 1990s. Stud Park Shopping Centre, opened in 1989, is the largest in the suburb. It houses the Rowville branch of the Eastern Regional Library, and is adjacent to the Rowville Community Centre.

\section{Case two: Wantirna South}

At the 2011 Census, Wantirna South had a population of 31,237. The Knox Private Hospital and Westfield Knox shopping centre are located in Wantirna. Wantirna South was mainly orchards until around 80 years ago. Demand for housing grew in the 1920s and Wantirna South and surrounding communities became a new place for housing development. One of the first buildings was the Wantirna South Post Office, which opened in December 1936. The Westfield Knox shopping centre (first built in the 1970s), includes Knox O-Zone, a popular night spot containing a licensed premises, restaurants, clubs and cinema. Swinburne University of Technology also has a campus located in Wantirna South.

\section{Findings}

\section{Demographics}

Differences in the general and social characteristics between the two suburbs were firstly explored.

Table 2 outlines some of the key demographic characteristics that may also influence health and levels of physical activity. The figures demonstrate that Wantirna-Wantirna South and Rowville do not differ significantly for many of these characteristics. For example, levels of disadvantage, as measured through both the SEIFA index and unemployment figures were very similar despite differences in levels of university or tertiary educational attainment (20.1 per cent for Wantirna-Wantirna South compared to 
13.4 per cent in Rowville). The two areas also do not differ remarkably in terms of gender profile, percentage of families with children or the average number of people per household.

Tab. 2. Key social and general demographic characteristics of Wantirna-Wantirna South, Rowville suburbs and Knox Local Government Area.

Source: ABS 2012; ABS 2006; ABS 2011.

\begin{tabular}{|c|c|c|c|}
\hline Population characteristic & $\begin{array}{l}\text { Wantirna and } \\
\text { Wantirna South }\end{array}$ & Rowville & Knox Average \\
\hline Median age & 42 & 36 & 38 \\
\hline Female population (\%) & 51.2 & 50.5 & 50.8 \\
\hline \multicolumn{4}{|l|}{ Country of birth: } \\
\hline Australia (\%) & 59 & 66.5 & 69 \\
\hline England (\%) & 3.9 & 3.4 & 4.4 \\
\hline Sri Lanka (\%) & 3.1 & 2.7 & 1.8 \\
\hline India (\%) & 3.6 & 2.3 & 2.0 \\
\hline Malaysia (\%) & 4.4 & 2.3 & 1.8 \\
\hline Unemployment (\%) & 4.8 & 4.3 & 4.6 \\
\hline Education to tertiary or university level (\%) & 20.1 & 13.4 & 13.7 \\
\hline SEIFA index ranking ${ }^{1}$ & 1,067 & 1,085 & - \\
\hline Families two children (\%) & 55.9 & 61.0 & 51.4 \\
\hline Median household weekly income (\$) & 1,455 & 1,706 & 1,401 \\
\hline Occupied private dwelling outright ownership (\%) & 42.0 & 30.9 & 34.3 \\
\hline Median monthly mortgage repayment (\$) & 1,733 & 1,820 & 1,733 \\
\hline Mortgage stress $(\%)^{2}$ & 8.7 & 13.6 & 11.2 \\
\hline Rent stress $(\%)^{3}$ & 4.1 & 4.2 & 5.8 \\
\hline Motor vehicles per household & 2.0 & 2.1 & 2.0 \\
\hline People per household & 2.9 & 3.1 & 2.8 \\
\hline
\end{tabular}

There were small differences in terms of the median age and age distribution as shown in figure 3, with a 42 year median for Wantirna-Wantirna South compared to a median age of 36 years in Rowville. In addition, Rowville had a higher percentage of people under the age of 17 years whilst Wantirna had a higher proportion of people aged over 50 years. Rowville also had a higher percentage of its population born in Australia.

Despite having higher median incomes, Rowville has lower levels of outright home ownership and higher levels of mortgage stress than Wantirna-Wantirna South. This was

\footnotetext{
${ }^{1}$ The lower the score the greater the disadvantage.

${ }^{2}$ Mortgage stress defined as households where mortgage payments are $30 \%$ or greater of household income.

${ }^{3}$ Rent stress defined as households where rent payments are $30 \%$ or greater of household income.
} 
not surprising due to a higher number of comparatively young families living in the area. Rent stress was comparable for the two localities.

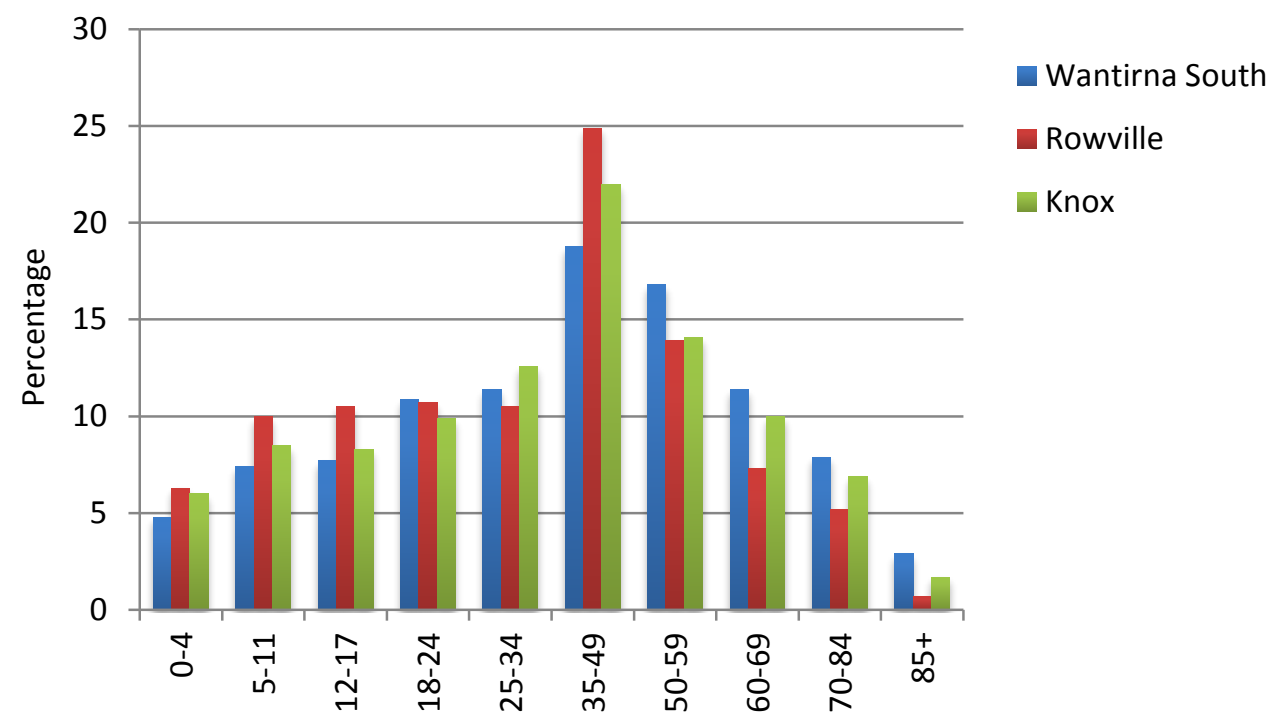

Fig. 3. Population profile Source: ABS census data 2011.

Land use mix

Figure 4 shows the proportion of the major land use zones within the two areas. While approximately 50 per cent of the land within both suburbs is zoned for residential use, the breakdown of the remaining 50 per cent is quite different. Within Rowville approximately 17 per cent of the land is within a special use zone. In Rowville, land in this zone is generally developed as golf courses (of which there are three in Rowville). The high proportion of the road zone within Wantirna South is as a result of Eastlink (a major north-south toll road) running through the suburb. The high proportion of land within the public park and recreation zone in Wantirna South is in part due to the Dandenong Valley Parkland (managed by Parks Victoria), which runs on the west side of east link along the Dandenong Creek Corridor, and the Blind Creek Corridor which connects to this park land.

Rowville contains a large employment area - the 'Scoresby Rowville Employment Precinct' (SREP). When fully developed this area is expected to produce 15,000 to 20,000 jobs. However, there is a slightly larger proportion of business land within Wantirna South than in Rowville. Much of this land is home to the Knox City Shopping Centre currently managed by Westfield, one of the largest shopping centres in the outer eastern suburbs. 


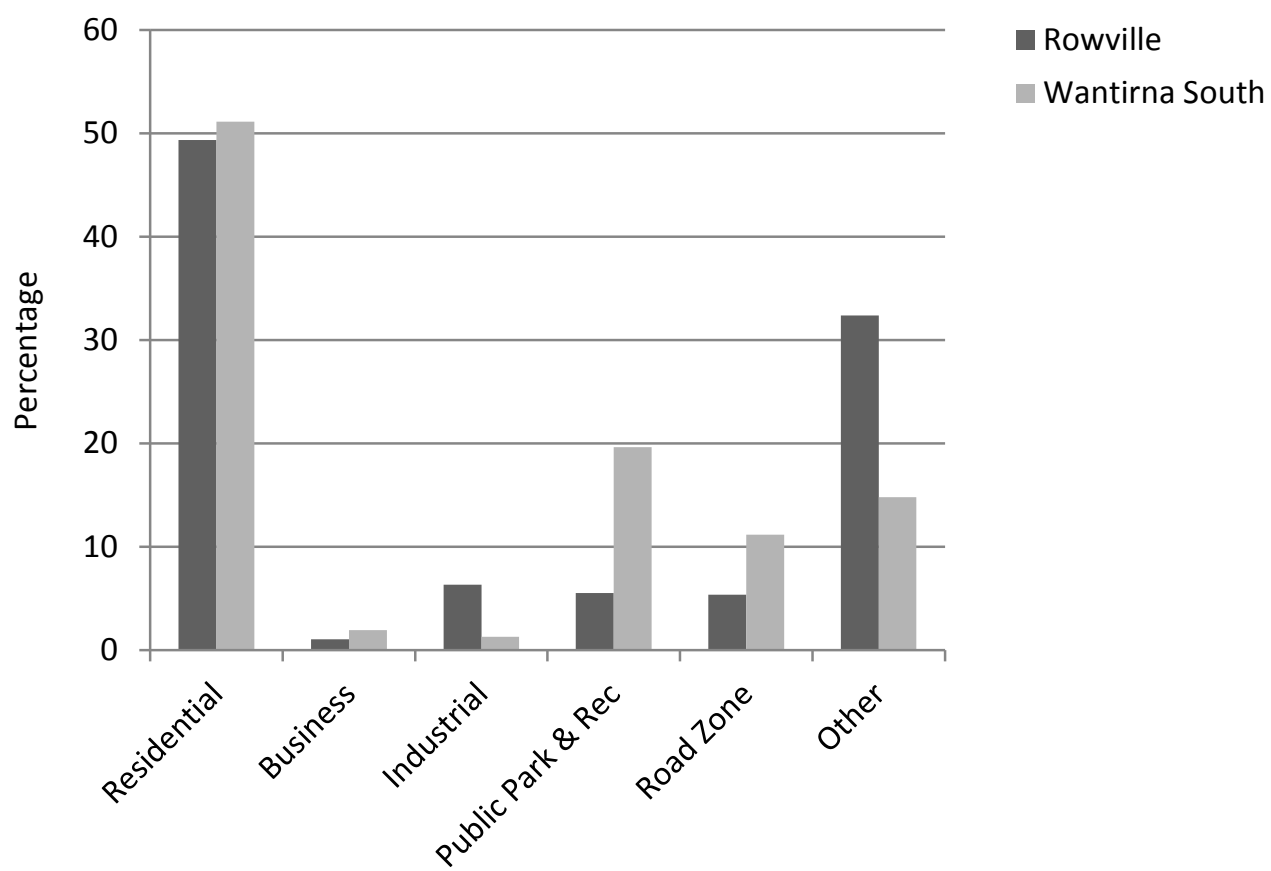

Fig. 4. Land use zoning Source: Knox Planning Scheme.

Housing density and size

In 2011 the population density in the City of Knox was 13.0 per hectare. This figure was far higher compared to Greater Melbourne, which had a population density of 4.0 persons per hectare (however this is perhaps not surprising as Greater Melbourne includes large areas of non-residential land).

Tab. 1. Population density in Wantirna-Wantirna South and Rowville Average Population Density per Ha

\begin{tabular}{ll} 
Wantirna and Wantirna South (average of Wantirna and Wantirna South) & 14.6 \\
\hline Rowville (average of Rowville, South, central and north) & 16.7 \\
\hline City of Knox & 13.0 \\
\hline
\end{tabular}

Source: Australian Bureau of Statistics 2011.

The majority of housing in Rowville is counted as large detached family homes. Comparison of the number of bedrooms identifies that over 95 per cent of all dwellings in Rowville have three or more bedrooms. This is higher than the proportion in Wantirna-Wantirna South (87 per cent), and the Knox average of 87 per cent. The proportion of smaller dwellings (one and two bedrooms) in Wantirna-Wantirna South is much higher (11 per cent) than Rowville (five per cent), and closer to the Knox average (12 per cent). 


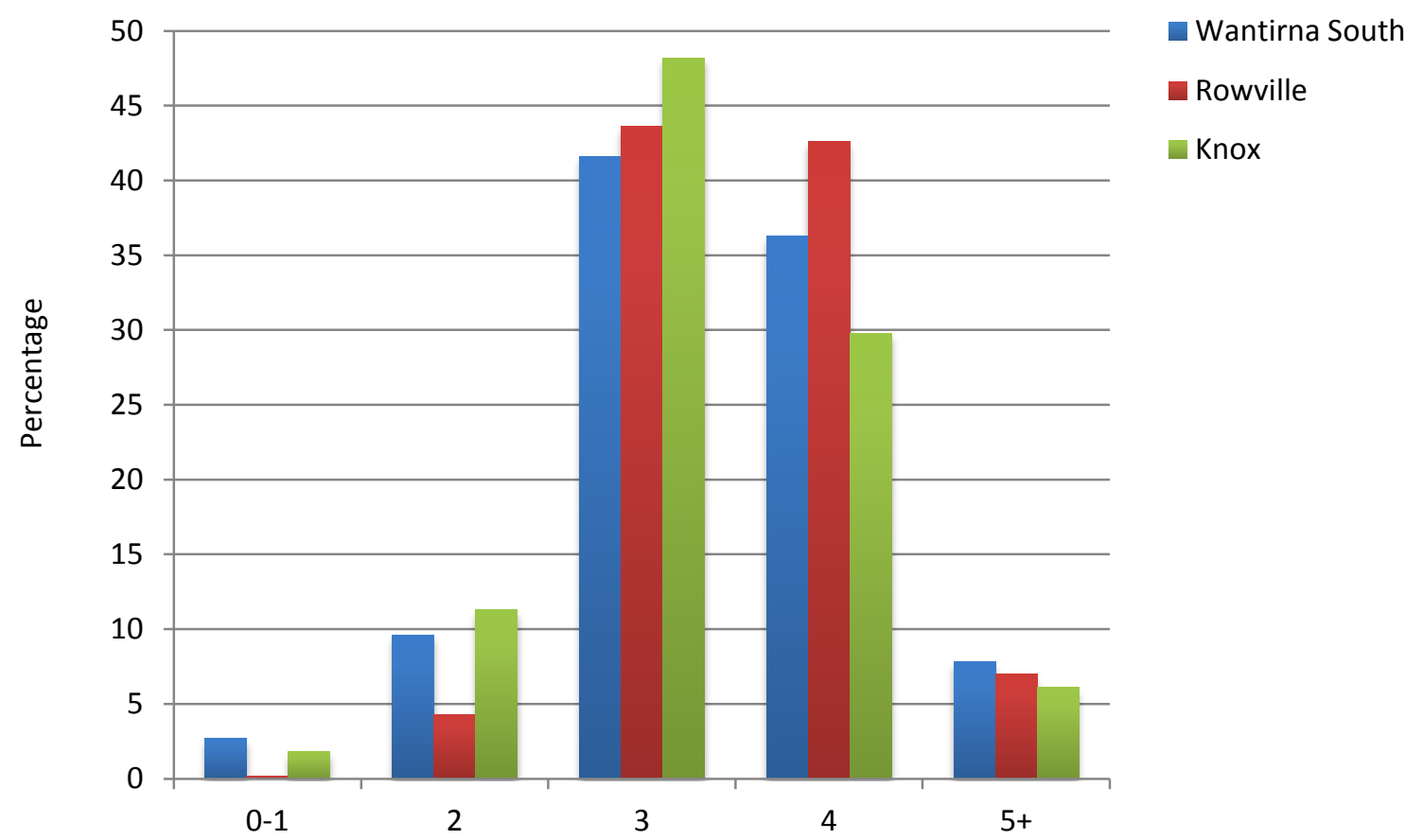

Fig. 1. Size of dwellings (number of bedrooms) Source: Australian Bureau of Statistics 2011.

Interestingly, the age of the majority of the residential building stock is fairly similar. Both suburbs were developed through the 1980s into the 1990s - although some parts of Wantirna South were developed a little earlier during the 1970s (see figure 6).

\section{Comparison of typical suburban streets}

While the majority of land across both areas was developed through the 1970s and 1980s, a number of differences can be drawn from an observation of two typical streets. Within Wantirna and Wantirna South there are a large number of 'pocket parks' which, although quite small (many no larger than an average house lot), connect many courts and cul-de-sacs with other streets, providing direct pedestrian access (see figure 7). This is also reflected in the relatively high amount of (Council owned) passive open space in Wantirna and Wantirna South (119.4 ha) when compared to Rowville (78.4 ha) (see also table 9), and the number of playgrounds per $\mathrm{km}^{2}$ (2.2 across Wantirna and Wantirna South and 1.1 in Rowville; see table 10).

Within Rowville, particularly in those areas developed through the 1990s, many of the houses are large relative to the size of the block. While the subdivision trend of courts and cul-de-sacs continued, there are significantly fewer pocket parks providing pedestrian and cycle access to adjoining streets. Many properties also have relatively small backyards (see figure 8). 


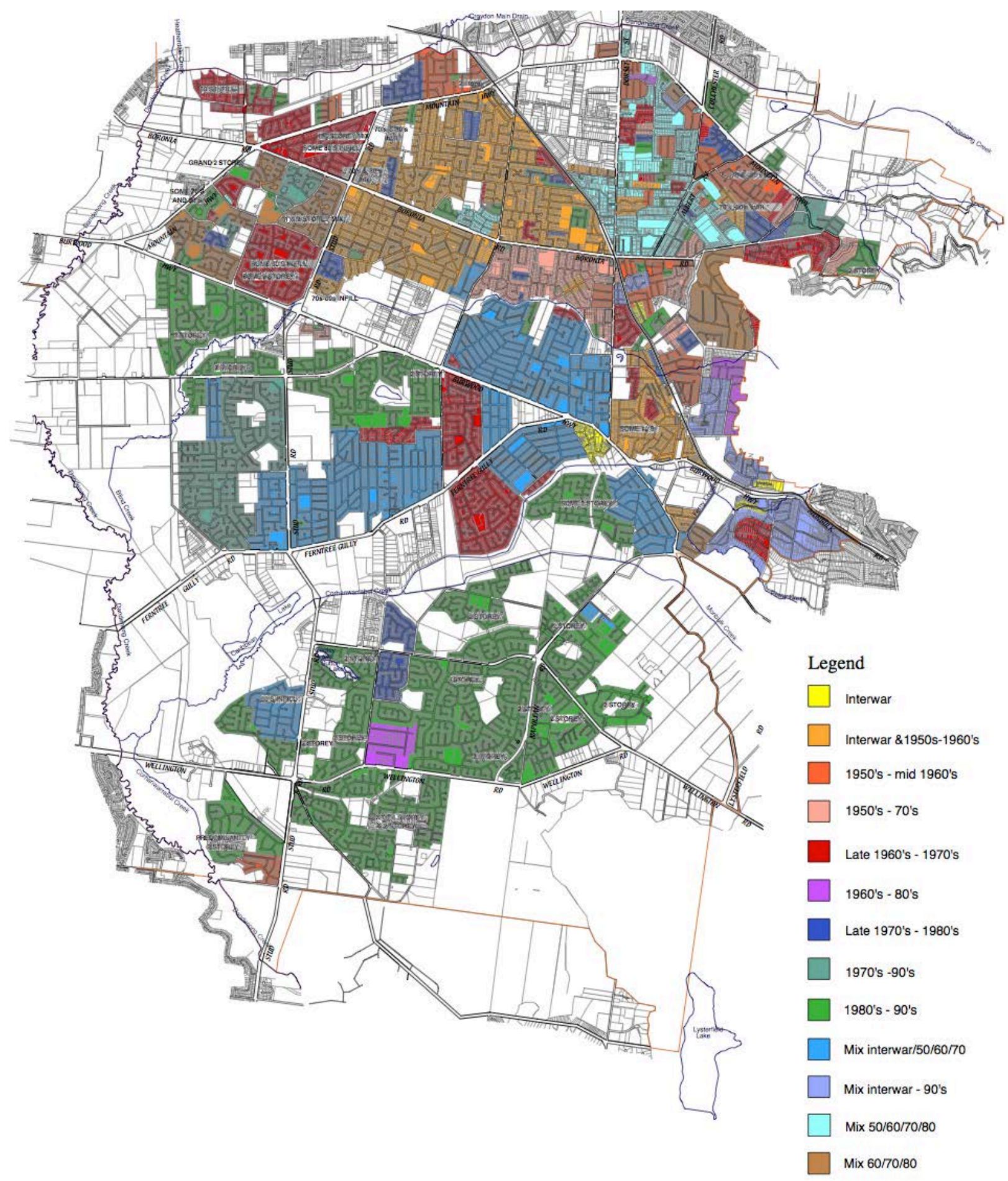

Fig. 2. Age of development

Source: Knox City Council unpublished. 


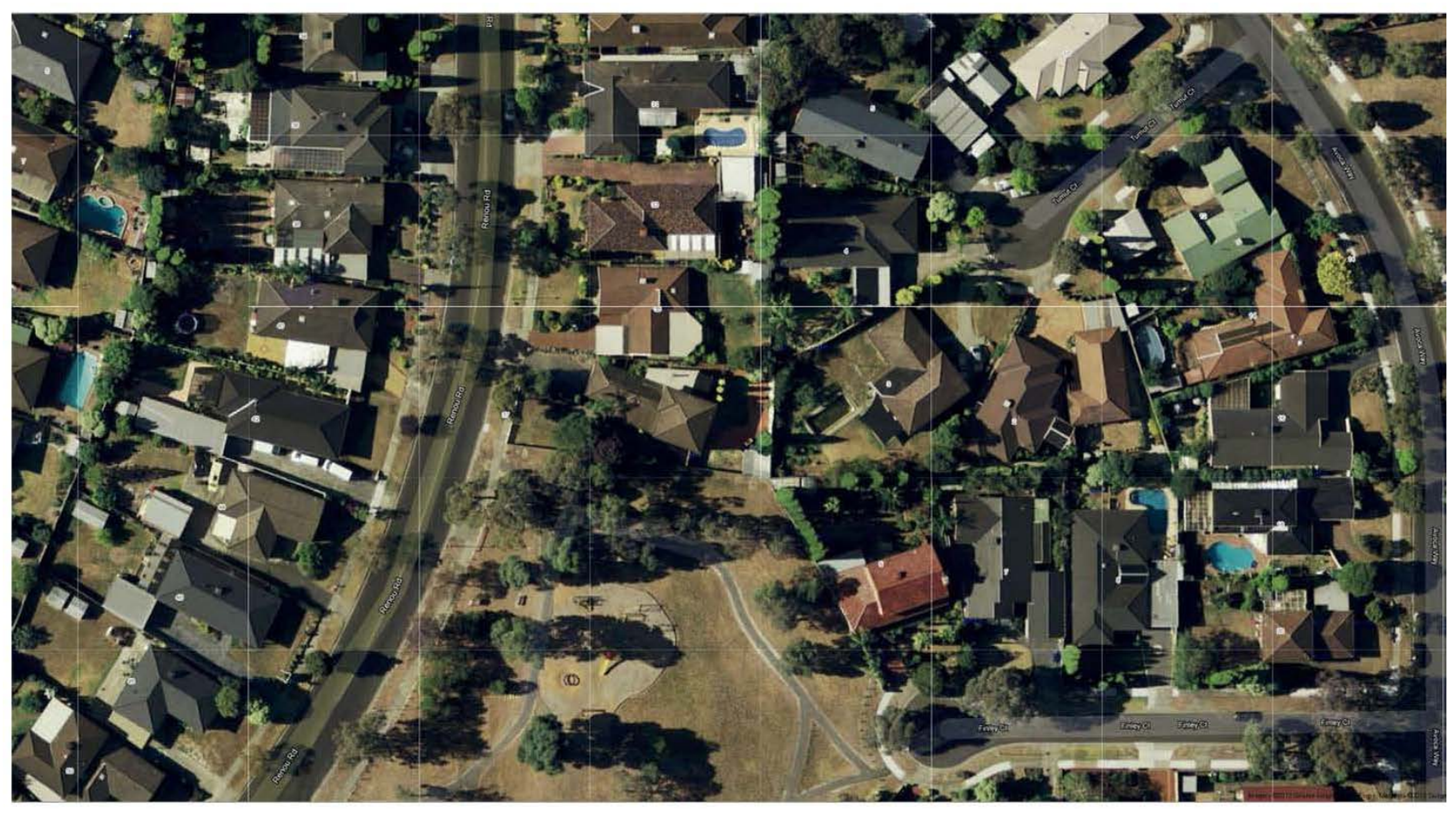

Fig. 3. Typical street pattern in Wantirna South.

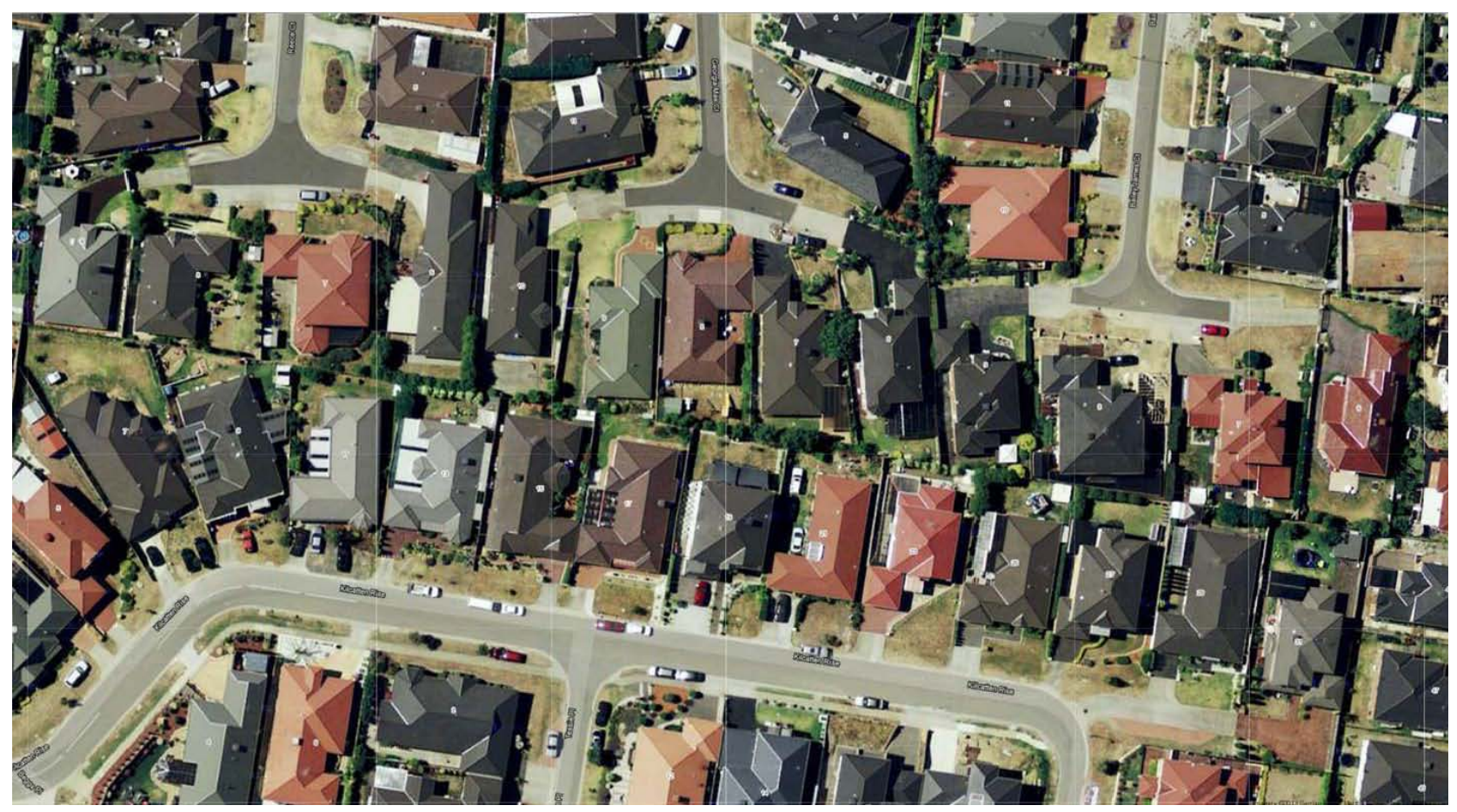

Fig. 4. Typical street pattern in Rowville.

Safety and perceptions of safety

Residents' perceptions of safety were also compared. The overall results of the perceptions of safety survey (conducted by Knox City Council online in 2012) did not 
reveal significant differences between the two areas. While the data suggest that Rowville residents are likely to feel safer than residents in Wantirna and Wantirna South, the presence of the Knox O-Zone (a popular night spot incorporating a large number of licensed venues, restaurants, clubs and a cinema) in Wantirna South is likely to have skewed the results such that residents' perceptions overall were not accurately reflected.

Table 4 provides the breakdown of the percentage of residents reporting feeling 'safe' or 'very safe' in the following situations:

Tab. 2. Perception of safety

\begin{tabular}{lll} 
& Rowville (\%) & $\begin{array}{l}\text { Wantirna and } \\
\text { Wantirna South (\%) }\end{array}$ \\
\hline Home alone (day) & 95 & 91.3 \\
\hline Home alone (night) & 92.3 & 86.7 \\
\hline Walking alone locally (day) & 97.5 & 97.8 \\
\hline Walking alone locally (night) & 51.3 & 43.5 \\
\hline
\end{tabular}

Source: Knox City Council perceptions of safety survey (unpublished).

In terms of what residents of these two areas would change in their neighbourhood to increase safety, table 5 shows that residents of Wantirna would like to see lighting improvements to improve safety at twice the rate of Rowville residents. Residents of Rowville would like to see changes to behaviour of community members and neighbours as a way of improving safety at twice the rate of Wantirna residents.

Tab. 3. Residents' preferred changes in the community/neighbourhood to increase safety.

\begin{tabular}{lll} 
Change in neighbourhood & Rowville (\%) & $\begin{array}{l}\text { Wantirna and } \\
\text { Wantirna South (\%) }\end{array}$ \\
\hline Lighting & 20.5 & 10.7 \\
\hline Environment (e.g. trees and litter) & 7.7 & 7.1 \\
\hline Changes to road / street & 10.2 & 14.3 \\
\hline Security improvements (e.g. gates, CCTV) & 2.6 & 3.6 \\
\hline Police, security personnel & 28.2 & 25 \\
\hline Initiatives for young people & 12.8 & 10.7 \\
\hline Alcohol & 5.1 & 3.6 \\
\hline Neighbours / behaviour in community & 10.2 & 21.4 \\
\hline Justice system response & 2.6 & 3.6 \\
\hline
\end{tabular}


Access to public transport and opportunities for non-motorised transport

Analysis of 'travel to work' data is important as travelling to work on public transport, on foot, or by cycling all provide opportunities for incidental physical activity. Analysis of ABS travel to work data reveal that a higher proportion of people in Wantirna-Wantirna South catch the train to work than in Rowville, while more people in Rowville drive their car to work than in Wantirna South.

A lower proportion of Rowville residents walk to work than in Wantirna-Wantirna South. In fact, the proportion of Wantirna-Wantirna South residents that walk to work is marginally higher than the Knox average. Some of the reasons that may explain the travel to work data for these two suburbs are considered below.

Tab. 4. Travel to work data.

\begin{tabular}{llll}
\hline Mode of travel to work & $\begin{array}{l}\text { Wantirna and } \\
\text { Wantirna South (\%) }\end{array}$ & Rowville (\%) & Knox (\%) \\
\hline Train & 7.7 & 5.1 & 6.3 \\
\hline Bus & 1 & 0.8 & 1.3 \\
\hline Car driver & 69.3 & 73 & 70.3 \\
\hline Car passenger & 4.8 & 5 & 4.6 \\
\hline Motorbike & 0.2 & 0.3 & 0.4 \\
\hline Bike & 0.3 & 0.2 & 0.4 \\
\hline Walk only & 1.4 & 0.5 & 1.1 \\
\hline
\end{tabular}

Table 7 shows the number of registered vehicles. This reveals that approximately three quarters of households in Rowville have at least two registered vehicles. This is higher than Wantirna South (approximately 66 per cent) and the Knox average (approximately 65 per cent). Conversely, there are fewer than two per cent of households in Rowville without a registered vehicle (1.9 per cent) compared with 5.2 percent in Wantirna-Wantirna South and the Knox average of 4.2 per cent.

Tab. 5. Number of registered motor vehicles per household.

\begin{tabular}{llll}
\hline Proportion of households & Rowville (\%) & $\begin{array}{l}\text { Wantirna and } \\
\text { Wantirna South (\%) }\end{array}$ & Knox (\%) \\
\hline None & 1.9 & 5.2 & 4.2 \\
\hline 1 motor vehicle & 21.7 & 26.9 & 28.5 \\
\hline 2 motor vehicles & 48.3 & 41.2 & 42.8 \\
\hline 3 or more vehicles & 26.2 & 24.7 & 22.2 \\
\hline No. of motor vehicles not stated & 1.9 & 2.1 & 2.3 \\
\hline
\end{tabular}


The travel to work data and the number of registered vehicles per household may be explained in part by the greater ease in which Wantirna residents can access major public transport networks. Only 40 per cent of residentially zoned land within Rowville is within $400 \mathrm{~m}$ of a bus stop. This compares with 45.8 per cent of land in Wantirna and Wantirna South. Analysis of all land within $400 \mathrm{~m}$ of a bus stop also reveals greater coverage in Wantirna-Wantirna South (67 per cent compared to 70.8 per cent).

While both Suburbs are serviced by the Principal Public Transport Network (PPTN) ${ }^{4}$, there is a far greater length of coverage in Wantirna-Wantirna South (17.6 km compared to $9.4 \mathrm{~km}$ ). There is also greater coverage of the PPTN - primarily running along Stud Road (north-south) and Burwood Highway (east-west) within Wantirna-Wantirna South.

Tab. 6. Access to bus stops and the PPTN.

\begin{tabular}{l|ll} 
& Rowville (\%) & $\begin{array}{l}\text { Wantirna and } \\
\text { Wantirna South (\%) }\end{array}$ \\
\hline $\begin{array}{l}\text { Proportion of all residentially zoned } \\
\text { land within 400m of a bus stop }\end{array}$ & 40.1 & 45.8 \\
\hline $\begin{array}{l}\text { Proportion of all land within 400m of } \\
\text { a bus stop }\end{array}$ & 67.0 & 70.8 \\
\hline Length of the PPTN $(\mathrm{km})$ & 9.4 & 17.6 \\
\hline
\end{tabular}

Figure 9 and figure 10 (below) show the coverage of land within 400m of a bus stop for both areas. Whilst this measured distance is direct ('as the crow flies'), it does highlight that there is a far greater network of bus stops across Wantirna and Wantirna South compared to Rowville. Access to the bus network is important due to the PPTN in both areas being comprised entirely of bus routes - there is no heavy or light rail in either suburb.

In both figures the PPTN is show in blue. In figure 10, which shows coverage in Rowville, the major gaps within residential areas are circled in red. Most of the other gaps across both areas are within non-residential areas, particularly to the west of Eastlink which includes land within the Dandenong Valley Parkland.

\footnotetext{
${ }^{4}$ The PPTN comprises a network of road and rail-based links connecting principal, major, and specialised activity centres within the urban growth boundary (Ramsey 2010). Additional local feeder bus services also exist within Knox, however these operate at less frequency than the PPTN.
} 


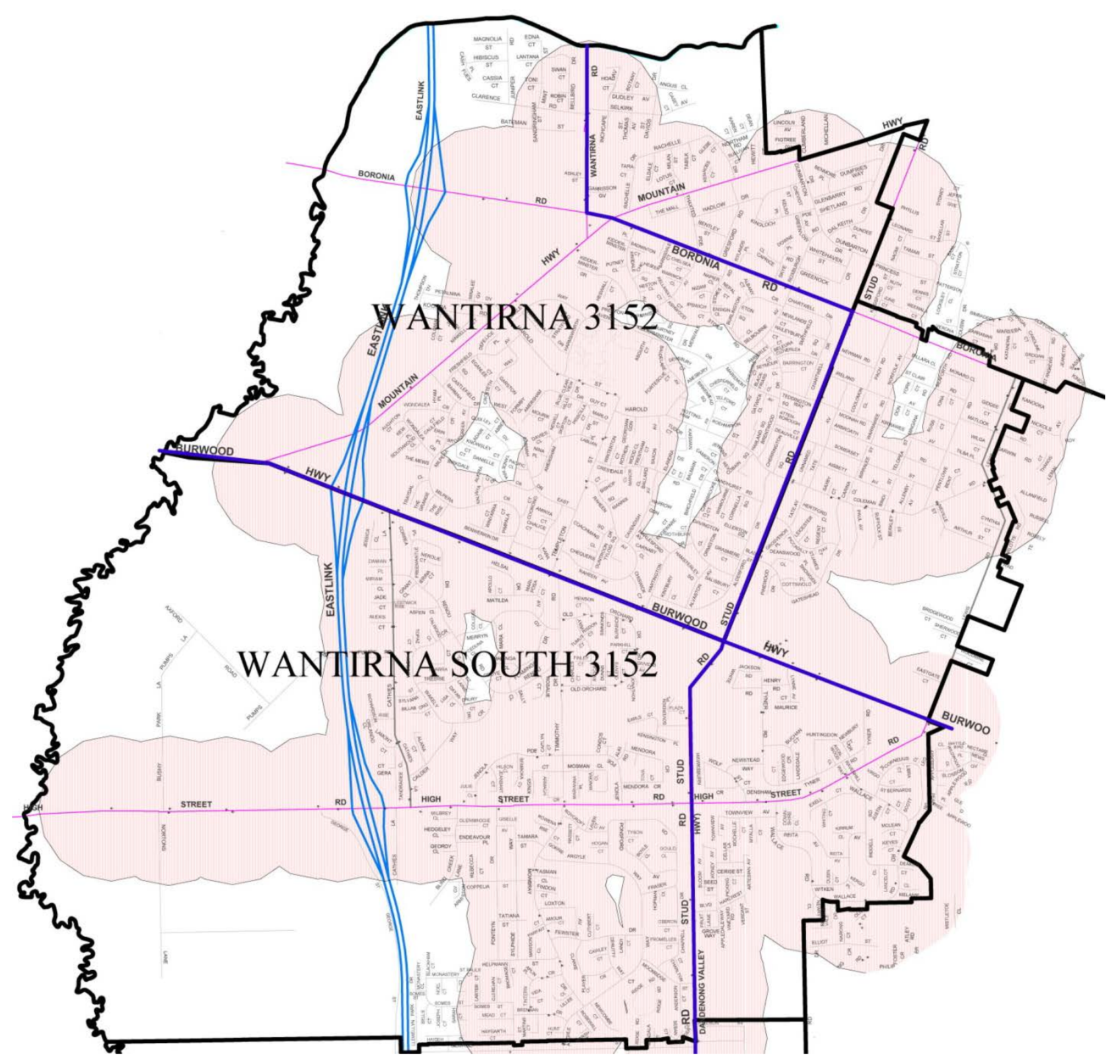

Fig. 5. Wantirna and Wantirna South land within $400 \mathrm{~m}$ of a bus stop (shaded in red). The PPTN is shown in dark blue. 


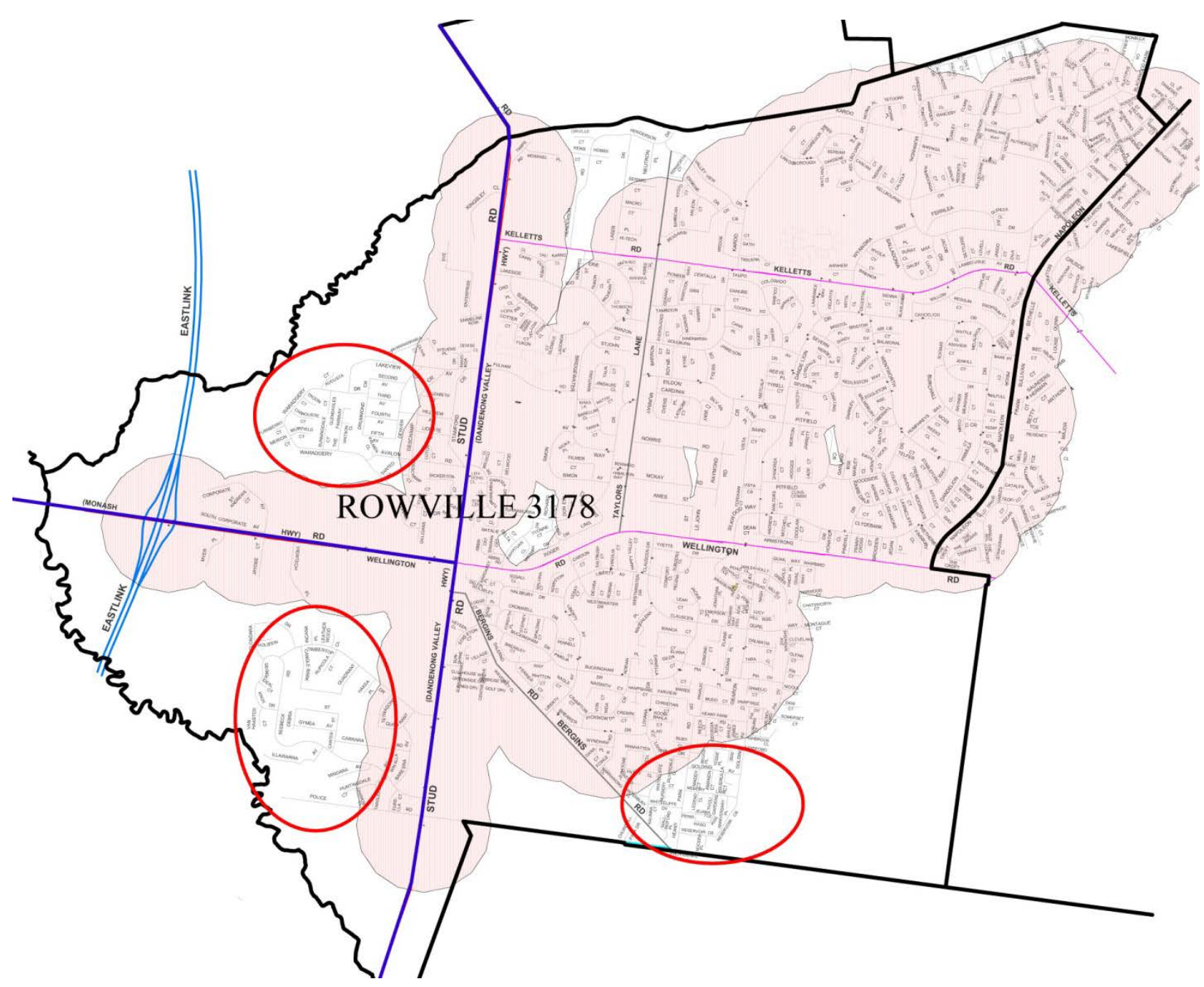

Fig. 6. Rowville land within $400 \mathrm{~m}$ of a bus stop (shaded in red). The PPTN is shown in dark blue. Major gaps within residential areas are circled in red.

Open space, playgrounds and shared paths

The Principal Bicycle Network (PBN) is a network of proposed and existing cycle routes that help people cycle for transport, and provide access to major destinations in the metropolitan area. The PBN is comprised of local roads and off-road paths. Within Wantirna and Wantirna South there is a greater length of the principal bicycle network than in Rowville (27.3 km in Wantirna-Wantirna South and 18.2 km in Rowville).

\section{Open space}

Table 9 provides a broad estimate of the amount of open space maintained by Council. There is 62 ha of open space within Knox that is within land owned or controlled government agencies such as Melbourne Water and VicRoads. 
While the total amount of open space is similar across these two areas, there are differences in the amount of usable open space. Much of the open space within Rowville is located within the future Stamford Park and is currently undeveloped and not accessible to the community (approx. 35 ha). Stamford Park is located in the far north west of Rowville, along the Corhanwarrabul Creek. Council has endorsed a master plan for this site that includes the restoration and recreation of wetlands (in partnership with Melbourne Water) and the creation of significant areas of passive open space.

Tab. 7. Open space maintained by Knox City Council.

\begin{tabular}{llll} 
& Rowville (ha) & $\begin{array}{l}\text { Wantirna and } \\
\text { Wantirna South (ha) }\end{array}$ & Knox (ha) \\
\hline $\begin{array}{l}\text { Active open space (sports fields and all } \\
\text { playing surfaces, e.g. netball, tennis, } \\
\text { athletics etc.) }\end{array}$ & 16.0 & 25.2 & 112.7 \\
\hline $\begin{array}{l}\text { Passive open space (excluding car } \\
\text { parks in reserves) }\end{array}$ & 78.4 & 119.4 & 430.5 \\
\hline $\begin{array}{l}\text { Conservation open space (bushland } \\
\text { areas managed by Council's } \\
\text { biodiversity team) }\end{array}$ & 18.8 & 49.5 & 131.5 \\
\hline $\begin{array}{l}\text { Undeveloped open space } \\
\text { Total }\end{array}$ & 54.9 & 23.5 & 102.8 \\
\hline
\end{tabular}

One important form of open space is playgrounds. Figure 11 shows the location of all playgrounds in Knox within a 400m buffer. As highlighted by the red and green ellipses there is a considerably greater coverage of playgrounds in Wantirna-Wantirna South (highlighted in green) when compared to Rowville (shown in red). Table 10 clearly shows that, in terms of number of playgrounds per square kilometer, Wantirna-Wantirna South and Rowville sit above and below the Knox average, respectively. Indeed, of the 207 playgrounds across Knox, 50 are in Wantirna-Wantirna South.

Tab. 8. Number of playgrounds.

\begin{tabular}{lll} 
& No of Playgrounds* & No. Playgrounds per $\mathbf{k m}^{2}$ \\
\hline Wantirna and Wantirna South & 50 & 2.2 \\
\hline Rowville & 24 & 1.1 \\
\hline Knox & 207 & 1.8 \\
\hline
\end{tabular}

* These figures do not include playgrounds within childcare and preschool facilities. 


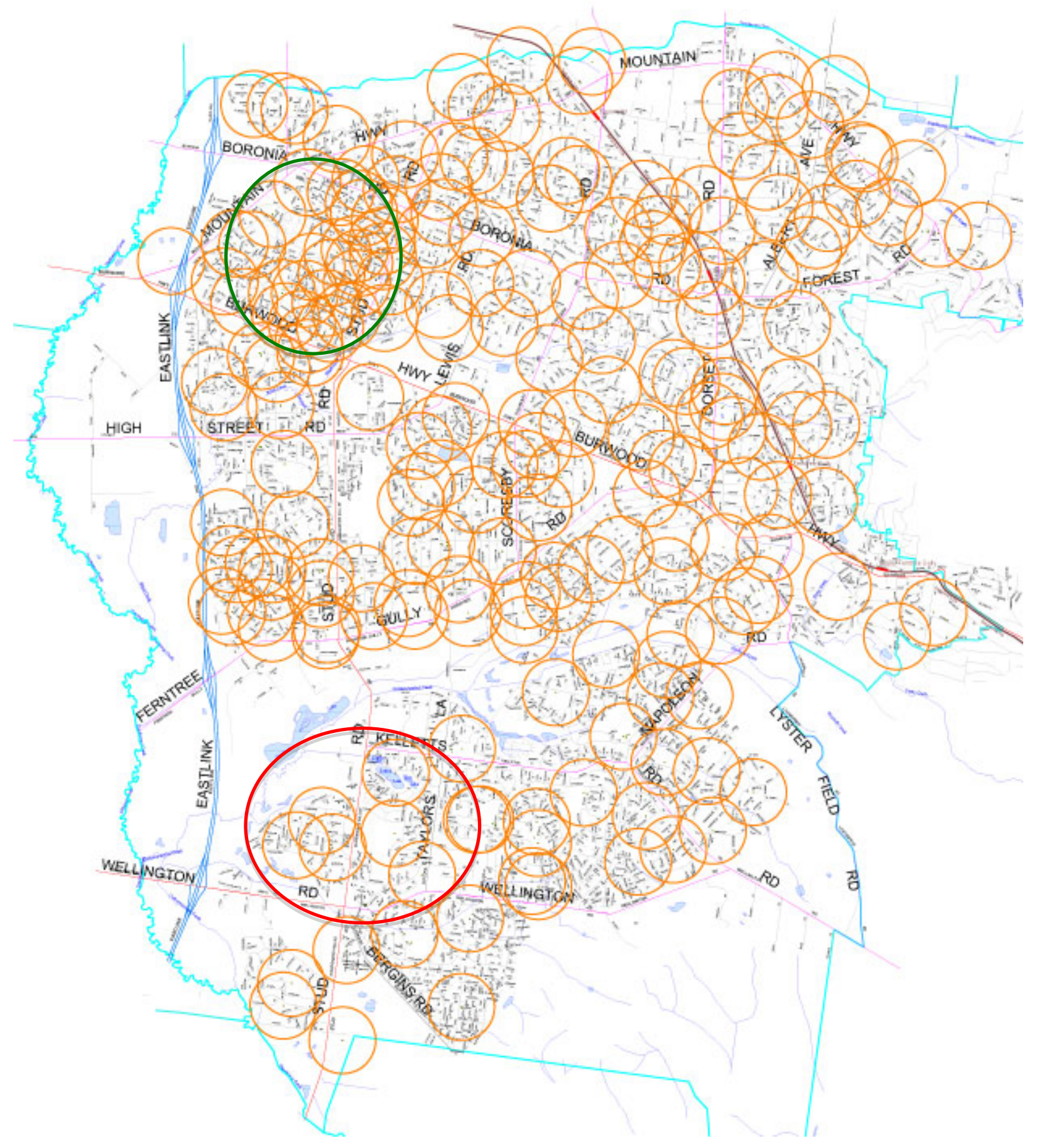

Fig. 7. Access to playgrounds in Knox. Playground areas are enclosed within an orange circle of $400 \mathrm{~m}$ buffer. High density playground areas in Wantirna-Wantirna South and low density playground areas in Rowville are circled in green and red, respectively. 


\section{Access to leisure}

Table 11 provides an overview of Council's active space facilities within the two areas. These figures do not include any private facilities (such as the Paul Sadler Swim School in Rowville and the 27ha Knox Regional Sports Park in Wantirna South). More detailed information on the location and access to leisure services across Knox will be available through the development of a new 'Leisure and Recreation Plan' (scheduled for 2013). Table 11 shows a higher number of tennis courts and cricket pitches and nets in Wantirna and Wantirna South, along with a greater area of ovals/pitches. In Rowville there are more Netball courts and outdoor basketball courts compared to Wantirna and Wantirna South.

Tab. 9. Council active space facilities.

\begin{tabular}{lll} 
& $\begin{array}{l}\text { Wantirna and } \\
\text { Wantirna South }\end{array}$ & Rowville \\
\hline Tennis courts & 45 & 21 \\
\hline Ovals / pitches & $197,446 \mathrm{~m}^{2}$ & $142,253 \mathrm{~m}^{2}$ \\
\hline Cricket pitches & 12 & 8 \\
\hline Cricket nets & 6 & 3 \\
\hline Rebound walls & 0 & 1 \\
\hline Netball courts & 2 & 6 \\
\hline Outdoor basketball courts & 1 & 2 \\
\hline
\end{tabular}

\section{Discussion}

The preceding analysis reveals key discrepancies between the suburbs of Rowville and Wantirna-Wantirna South, which are otherwise largely comparable areas.

There was a marked pattern of Wantirna and Wantirna South having many of the physical environment attributes that are likely to contribute to the observed reduced risk of obesity and improved health. These included:

- more open space (specifically more active open space) and more playgrounds, with a greater coverage

- a greater coverage of residential land within $400 \mathrm{~m}$ of a bus stop

- a greater length of the PPTN and the Principal Bicycle Network.

Conversely, within Rowville:

- more residents travelled to work using private motorised transport

- there was a higher proportion of households with three or more cars. 
These findings are consistent with evidence which demonstrates that residents who live in environments which have a high reliance on motorised transport, have reduced access to active transport options, and have less access to open space are more likely to have a higher risk of obesity (Frank et al. 2006; Frumkin et al. 2004). Furthermore, these findings support the espoused broader link between urban form, physical activity and obesity (McCormack \& Shiell 2011).

Whilst most of the findings were consistent with the existing research, there were fewer differences between the referent suburbs for perceived levels of safety, which has previously been demonstrated to impact on physical activity levels. It is important to note, however, that the data on reported perceptions on safety may be skewed due to the inclusion of a concentration of restaurants and bars within Wantirna. This is important for further research in Knox to get a better understanding of perceptions of safety within the community and other barriers to incidental and structured physical activity related to safety and perceptions of safety.

Unfortunately, there were extremely limited data available to support the analysis of access to leisure and recreation faculties beyond those owned by Council. Therefore it was not possible to draw meaningful conclusions around different levels of access between the two areas.

\section{What we have learnt from the process}

Integrated planning is critical to the implementation of any possible policy interventions, not only in Rowville, but across the whole municipality. One of the most important findings from this paper was the need to ensure that the impact upon health is considered in all strategic and urban planning work.

\section{Rowville Plan}

This paper suggests that there are a number of differences in the physical activity environment between Wantirna-Wantirna South and Rowville. The important questions to ask in developing the Rowville Plan revolve around what policy interventions could reduce overweight and obesity. Drawing on the literature and an understanding of these differences - many of which highlighted that Rowville's physical activity environment could be improved to reduce the risk of obesity - this paper will form an important input to the development of the Rowville Plan. This section identifies possible interventions in the built environment to reduce the relative risk of obesity and enable better population health in Rowville. 
The development of the Rowville Plan is supported by the Rowville Community Reference Group. This group comprises residents, business owners and representatives from various local groups and clubs. One of the outcomes sought through the development of the Rowville Plan is local ownership of the plan, particularly given that the project is a review of a current structural plan that was the subject of much community angst around the land use and development outcomes sought. Because the Rowville Plan represents an opportunity to develop a much more holistic plan for the next 20 years it will be important to embed discussions about healthy environments into discussions with reference group members and the broader community. This could have two benefits: firstly, it can ensure that population health is captured as an important planning issue; and secondly, it can increase understanding of the rationale behind aspects of the final plan that may seek to improve population health.

One obvious aspect of the Rowville environment that could be improved is access to public transport and non-motorised forms of transport. This will require a combination of approaches, and in some cases require further investigation.

In terms of improving access to public transport (largely a state government responsibility), this will require continued advocacy from both Council and the Eastern Transport Coalition (ETC) for both general and specific improvements. The ETC consists of Melbourne's seven eastern Metropolitan Councils and represents approximately one million residents. The ETC advocates for sustainable and integrated transport services to reduce the level of car dependency to secure the economic, social and environmental wellbeing of Melbourne's outer-east. The ETC aims to work in partnership with federal and state governments.

There are two specific improvements which could make a substantial difference to access to public transport in Rowville: Rowville Rail and an improved bus interchange at the Stud Park Shopping Centre. The state government has recently funded a \$2 million feasibility study of a 12 kilometre rail line between Huntingdale Station and Rowville (scheduled for completion by mid-2013). A rail line to Rowville was one of the rail network developments proposed in the 1969 Melbourne Transportation Plan (SKM 2012). Importantly, a Rowville rail line would service Monash University (which has over 23,000 students and adjoins a large scientific precinct). The state government study will provide greater understanding of service levels and travel times, patronage projections, constructability, environmental and social impacts, and costs. The ETC and Knox City Council are currently calling on the state government to release the final report for stage 1 of the Rowville Rail feasibility study which is almost six months overdue. 
Currently the north-south SmartBus route does not connect to the bus interchange at Stud Park Shopping Centre. The Rowville Plan (which is focused around this shopping centre) can and should allow for the provision of an improved interchange as part of any redevelopment of the shopping centre. The interchange should be designed in a way in which it could be incorporated into a future railway station layout.

As outlined above, in table 9 much of the open space within Rowville is located within the future Stamford Park and is currently undeveloped and not accessible by the community (approx. 35ha). The redevelopment of Stamford Park will provide additional active, passive and conservation open space in Rowville. The Stamford Park Master Plan (Knox City Council 2013) includes a network of shared paths, including an additional crossing of Corhanwarrabul Creek. This will provide improved access to the adjacent Dandenong Valley Parklands. Development of Stamford Park will have a number of benefits beyond improvements to the physical activity environment.

In addition, although not specifically analysed in this paper, the literature suggests that improvements to pedestrian amenity could play a role in making walking more attractive. Therefore, in terms of recommendations for further research, it would be useful to better understand the motivations and barriers to walking and cycling in Rowville, specifically those barriers relating to safety and perceptions of safety, and the amenity of the general environment.

Study's strengths and limitations

This paper has engaged in research of an interdisciplinary nature, 'crossing professional boundaries' that Higgins (2010, p. 108) refers to. The process of writing this paper has provided a number of opportunities for conversations across Council about the differences in the physical environment between Wantirna-Wantirna South and Rowville, and how this may be influencing levels of physical activity. This research will form an input to the development of the Rowville Plan.

For this paper, analysis of factors influencing obesity was limited to the physical activity environment. Whilst differences in physical activity environments are not the only differences between these suburbs, they are part of a complex interrelated web of determinants that, when addressed in a complementary and holistic way through policy and planning, can make a substantial positive impact on the health and wellbeing of residents.

Some of the specific limitations of this research included a lack of comparative data around safety and perceptions of safety, and access to leisure and recreation. The authors note that more detailed information on the location and access to leisure services across Knox will be available through the development of a new Leisure and Recreation Plan (scheduled for 2013). Additionally, there were a number of elements identified in the 
literature that were not considered in this paper, such as the quality of open space, route directness, connection of pathways, and number of trees.

One of the main challenges of this paper was a limited ability within Council to complete detailed and more meaningful spatial analysis. For this reason, much of the analysis is observational; therefore a causal relationship between the built environment and risk of obesity cannot be categorically demonstrated.

\section{Conclusion}

Using a comparative case study investigation to understand how differences in urban form may influence physical activity, this paper revealed numerous small, but cumulative differences between Wantirna-Wantirna South and Rowville. While these two suburbs do not differ remarkably in terms of social and other demographic characteristics, there were differences in terms of the mix of land uses, size of dwellings, provision of open space (and specifically playgrounds), and access to public transport and non-motorised forms of transport.

The findings showed that Wantirna and Wantirna South have many of the physical environmental attributes that contribute to a reduced risk of obesity and a healthier suburb, such as:

- more open space (and specifically more playgrounds)

- better access to public transport, including the Principal Bicycle Network.

While conversely, Rowville (with a relatively higher risk of obesity) has:

- more residents travelling to work using private motorised transport

- a higher proportion of households with three or more cars.

These findings are broadly consistent with the literature reviewed herein and support the espoused broader link between urban form, physical activity and obesity.

The differences in the built form between the two suburbs may, in part, explain the increased risk of obesity in Rowville. Future strategic and urban planning decisions for the suburb of Rowville (and the entire municipality) should consider the potential impact upon the health of the population. Within Rowville there is an opportunity to consider this in 2013 through the development of the Rowville Plan. One obvious aspect of the Rowville environment that could be improved is access to public transport and nonmotorised forms transport. This will require a combination of approaches, and in some cases require further investigation. Development of the new Rowville plan will provide 
an opportunity for additional active, passive and conservation open space in addition to increased provision of, and access to shared paths. Findings from this study have the potential to inform future policy and planning both within Rowville and, more broadly, to better population health.

\section{References}

Australian Bureau of Statistics (ABS) 2006, 2006 Census data, viewed October 2013, <http://abs.gov.au/websitedbs/censushome.nsf/home/historicaldata2006>.

ABS 2011, Census of Population and Housing, profile.id, viewed February 2013, $<$ http://profile.id.com.au/knox/about-profile-id>.

Barton, H. 2010, 'Strengthening the Roots of Planning', Planning Theory and Practice, vol. 11, no. 1, pp. 91-113.

Capon, A.G. \& Blakely, E.J. 2007, 'Checklist for health and sustainable communities', NSW Public Health Bulletin, vol. 18, no. 4-3, pp. 51-4.

Cao, X., Handy, S.L. \& Mokhtarian, P.L. 2006, 'The Influences of the Built Environment and Residential Self-Selection on Pedestrian Behavior: Evidence from Austin, TX', Transportation, vol. 33, no. 1, pp. 1-20.

Department of Health [Vic] (DH) \& Mosaic $^{\odot}$ 2008, Prevention Health Data Profile, unpublished raw data.

DH 2008, Health Status of Victorians: Victorian Population Health Survey (VPHS), viewed October 2013, <http://www.health.vic.gov.au/healthstatus/survey/vphs.htm>.

DH 2013, Healthy Together Victoria, Prevention and Population Health, viewed October 2013, <http://www.health.vic.gov.au/prevention/healthytogether.htm>.

Duncan, M., Spence, J. \& Mummery, W. 2005, 'Perceived environment and physical activity: a meta-analysis of selected environment characteristics', International Journal of Behavioural Nutrition and Physical Activity, vol. 2, no. 11.

Frank, L., Kavage, S. \& Litman, T. 2006, Promoting public health through Smart Growth, Smart Growth, Vancouver.

Frumkin, H., Frank, L. \& Jackson, R. 2004, Urban sprawl and public health: designing, planning and building for healthy communities, Island Press, Washington.

Garrard, J. 2009, Taking action on obesogenic environments: Building a culture of active, connected communities, National Preventative Health Taskforce, Canberra.

Greenwald, M. \& Bournet, M. 2001, Built environment as determinant of walking behaviour: Analysing nonwork pedestrian travel in Oregon, Transportation Research Board of the National Academies, Washington. 
Giles-Corti, B. \& Donovan, R.J. 2003, 'Relative influences of individual, social environmental, and physical environmental correlates of walking', American Journal of Public Health, vol. 93, no. 9, pp. 1583-9.

Giles-Corti, B., Broomhall, M., Knuiman, M., Collins, C., Douglas, K., Ng, K., Lange, A. \& Donovan, R.J. 2005, 'Increasing walking: how important is distance to, attractiveness, and size of public open space?', American Journal of Preventative Medicine, vol. 28, no. 2, pp. 169-76.

Higgins, M. 2010, 'Health inequities and Place', Planning Theory and Practice, vol. 11, no. 1, pp. 91-113.

IdConsulting 2012, City of Knox, Population density, 2011, Enumerated, Persons, Persons per hectare, <http://www.id.com.au/knox/atlas/Default.asp?bhcp=1>.

Jabareen, Y.R. 2006, 'Sustainable urban forms: Their typologies, models, and Concepts', Journal of Planning and Education and Research, vol. 26, no. 1, pp. 38-52.

Kelty, S.F., Giles-Corti, B. \& Zubrick, S.R. 2008, 'Physical Activity and Young People: The impact of the built environment in encouraging play, fun and being active', in N. Beaulieu (ed.), Physical Activity in Children: New Research, Nova Science Publishers, Hauppauge, NY, pp. 7-33.

Kent, J., Thompson, S.M. \& Jalaludin, B. 2011, Healthy Built Environments: A review of the literature, City Futures Research Centre, UNSW, Sydney, <http://www.be.unsw .edu.au/programs/healthy-built-environments-program/literature-review $>$.

Knox City Council 2013, Stamford Park Master Plan Report February 2013, Knox City Council, Victoria, viewed February 2013, <http://www.knox.vic.gov.au/Files/ Planning/Stamford_Park_Masterplan_Report_February_2013.pdf $>$.

Lee, A. \& Maheswaran, R. 2010, 'The health benefits of green spaces: a review of the evidence', Journal of Public Health, vol. 33, no. 2, pp. 212-22.

Maller, C., Townsend, M., St Leger, L., Henderson-Wilson, C., Pryor, A., Prosser, L. \& Moore, M. 2008, Healthy parks, healthy people: The health benefits of contact with nature in a park context. A review of relevant literature, School of Health and Social Development, Deakin University, Melbourne.

McCormack, G.R. \& Shiell, A. 2011, 'In search of causality: a systematic review of the relationship between the built environment and physical activity among adults', International Journal of Behavioural Nutrition and physical activity, vol. 8, no. 125.

Moodie, R., Swinburn, B., Richardson, J. \& Somaini, B. 2006, 'Childhood obesity - a sign of commercial success, but a market failure', International Journal of Paediatric Obesity, vol. 1, vo. 3, pp. 133-8. 
National Heart Foundation of Australia (Victoria Division) 2004, Healthy by Design: a planner's guide to environments for active living, National Heart Foundation of Australia (Victoria Division), Melbourne.

National Preventative Health Taskforce (NPHT) 2009, Obesity in Australia: A Need for Urgent Action, Australian Government: Department of Health.

Norman, G., Nutter, S., Ryan, S., Sallis, J., Calfas, K. \& Patrick, K. 2006, ‘Community Design and Access to Recreational Facilities as Correlates of Adolescent Physical Activity and Body-Mass Index', Journal of Physical Activity And Health, vol. 3, Suppl. 1, pp. s118-28.

Owen, N., Cerin, E., Leslie, E., duToit, L., Coffee, N., Frank, L., Bauman, A., Hugo, G., Saelens, B. \& Sallis, J. 2007, 'Neighborhood Walkability and the Walking Behavior of Australian Adults', American Journal of Preventative Medicine, vol. 33, no. 5, pp. 387-95.

Ramsey, E. 2010, 'The review of Melbourne’s Principal Public Transport Network', Australasian Transport Research Forum, Australian Government: Department of Infrastructure and Regional Development, Canberra, Australia.

Sinclair Knight Mertz (SKM) 2012, Rowville Rail Study Stage 1 Feasibility Report, Public Transport Victoria, Melbourne.

Sunarja, A., Wood, G. \& Giles-Corti, B. 2008, A Factsheet on Healthy Public Open Space Design for Multi-Users and Multi-Uses, Centre For The Built Environment and Health, School of Population Health, The University of Western Australia, Perth, WA, viewed 25 January 2013, <http://www.sph.uwa.edu.au/research/cbeh/projects/ $? \mathrm{a}=264575>$.

Sparling, P.B., Owen, N., Lambert, E.V. \& Haskell, W.L. 2000, 'Promoting physical activity: the new imperative for public health', Health Education Research, vol. 15, no. 3, pp. 367-76.

Corderoy, A. 2010, 'Obesity is now more deadly than smoking', Sydney Morning Herald, 9 April, viewed November 2013, <http://www.smh.com.au/lifestyle/diet-andfitness/obesity-is-now-more-deadly-than-smoking-20100408-rv5l.html>.

Vandenbroeck, P., Goossens, J. \& Clemens, M. 2007, Obesity System Influence Diagram, ShiftN, viewed November 2013, <http://www.shiftn.com/obesity/FullMap.html>.

VicHealth 2010, Participation in physical Activity: A determinant of mental and physical health - Research Summary, VicHealth, Carlton, Victoria.

Waters, E., de Silva-Sanigorski, A., Burford, B.J., Brown, T., Campbell, K.J., Gao, Y., Armstrong, R., Prosser, L. \& Summerbell, C.D. 2011, 'Interventions for preventing 
obesity in children', The Cochrane Library, Issue 12, viewed November 2013, $<$ http://onlinelibrary.wiley.com/doi/10.1002/14651858.CD001871.pub3/full>.

Wyatt, S.B., Winters, K.P. \& Dubbert, P.M. 2006, 'Overweight and obesity: prevalence, consequences, and causes of a growing public health problem', The American Journal of the Medical Sciences, vol. 331, no. 4, pp. 166-74. 